\title{
ОБУЧЕНИЕ СТУДЕНТОВ С ОСОБЫМИ АДАПТИВНЫМИ ВОЗМОЖНОСТЯМИ В ВЫСШЕЙ ШКОЛЕ
}

\section{EDUCATION OF STUDENTS WITH SPECIAL ADAPTIVE CAPABILITIES IN HIGHER EDUCATION}

\section{N. Anisimova}

Summary: The article is devoted to the study of the problem of teaching students with special adaptive capabilities in higher education. The author outlines the relevance, significance and degree of scientific development of the topic of research. A list of barriers to the dissemination of experience and, in general, the development of the institute of inclusion in higher education has been formulated. It has been suggested and justified that the inclusion of inclusive tutoring will facilitate the formulation of an effective learning mechanism for students with special adaptive capabilities. It is emphasized that the effect of this kind of mentoring will be effective, provided that the inclusive competence of all actors in the education ecosystem, especially teachers, is formed and developed.

Keywords: special adaptive capabilities, students with disabilities, inclusion, inclusive tutor, inclusive competence of teachers.
$\mathrm{H}$ еоспорим тот факт, что современный мир переживает системные социокультурные, энергетические, финансовые и иные кризисы, которые обуславливают противоречия в общественном развитии и стимулируют поиски новых смыслов в организации социальных моделей государств, уделяя пристальное внимание к человеческому ресурсу. В этой связи, перед современной системой образования стоит задача формирования личности, которая умеет адаптироваться к многообразию мира, взаимодействовать с другими, личности толерантной, коммуникабельной, самостоятельно мыслящей и способной к сопереживанию и состраданию. Все это придает особую актуальность, если речь идет о лицах с особыми адаптивными возможностями.

Особые адаптивные возможности - это потребности в условиях, необходимых для оптимальной реализации актуальных и потенциальных возможностей (когнитивных, энергетических, эмоционально-волевых, мотивационных и пр.), которые может проявить индивид с нарушениями развития в процессе обучения [12]. Данный феномен изучался как в зарубежной, так и российской науке широчайшим спектром авторов: в отечественной психологии посвящены труды К.А. Абульхановой-Славской, Л.С. Выготского, А.В. Запорожца, С.Л. Рубинштейна и др.; в зарубежной психологии - труды Дж. Г. Мида, М. Монтессори, С. Роткера, Э. Торндайка, Р. Штайнера, Э.
Анисимова Нина Анатольевна

к.т.н., дочент, ФГБОУ ВО «Волжский государственный университет водного транспорта» (г. Нижний Новгород) nina72a@gmail.com

Аннотация: Статья посвящена изучению проблемы обучения студентов с особыми адаптивными возможностями в высшей школе. Автором обозначена актуальность, значимость и степень научной разработанности темы исследования. Сформулирован перечень барьеров, препятствующих распространению опыта и, в целом, развития института инклюзии в высшей школе. Выдвинуто и обосновано предположение 0 том, что формулировке эффективного механизма обучения студентов с особыми адаптивными возможностями будет способствовать интеграция инклюзивного тьюторства. Делается акцент на том, что результат от такого рода наставничества будет эффективным при условии формирования и развития инклюзивной компетенции всех субъектов экосистемы образования, в первую очередь, педагогов.

Ключевые слова: особые адаптивные возможности, студенты с ограниченными возможностями здоровья, инклюзия, инклюзивное тьюторство, инклюзивная компетенция педагогов.

Эриксона и др. Социально-психологическая адаптация как приспособление человека к социальной среде рассматривается в научных работах А.А. Реана, Т. Парсонса, Ж. Пиаже и др. Психологические механизмы адаптации анализируются в работах Б.Н. Алмазова, С.П. Иваненкова, А.Б. Петровского, А.А. Реана и др. Адаптация и интеграция к традиционной образовательной организации изучается Б.Г. Ананьевым, Д.А. Андреевой, Л.Н. Винокурова, Т.А. Голубевой, Г.Ф. Куминой, Л.Н., ЭИ. Леонграда и др. Проблемы развития и саморазвития личности в процессе обучения исследовали С.О. Анохина, Д.Б. Богоявленская, П.Я. Гальперин, В.В. Давыдов, О.А. Денисова, И.Л. Лернер, Л.М. Фридман, Д.Б. Эльконин, Е.В. Бондаревская, А.В. Петровский, В.В. Сериков, И.С. Якиманская и др.

Студенческая молодежь сособыми адаптивными возможностями - это, по мнению М.А. Федоровой и соавт., особая категория молодых людей, состояние здоровья или развития которых препятствует их самообслуживанию, самостоятельному передвижению, ориентации, контролю своего поведения, общению, освоению образовательных программ, иными словами, адаптации в обществе без специально созданных условий [13]. В этой связи, в образовательной организации должен быть сформирован особый механизм адаптированного образовательного процесса, создано особое микро-социальное пространство (за пределами семьи), которое 
должно учитывать их социально-психологические и образовательные потребности. Данный тезис приобретает особую значимость в той связи, что на современном этапе, несмотря на положительный опыт интеграции инклюзии в институт высшей школы (МГТУ им. Н.Э. Баумана, ЛГУ им. А.С. Пушкина, РГПУ им. А.Э. Герцена, Северо-Западный государственный заочный технический университет, СПГХПА им. А.Л. Штиглица и пр.) [9], он по-прежнему остается локальным. С точки зрения отечественных ученых, среди которых Е.Е. Зорина [6], В.3. Кантор, Ю.Л. Проект [7], О.А. Козырева [8] и др., а также зарубежных авторов, к примеру К. Андхарада, Е. Бэкетта [15], П. Санчеса, Р. Родригеса, Р. Мартинеса [17], М. Пирса, Дж. Грея, Г. Кембелл-Эванса [16] и др., приоритетными причинами следует считать: во-первых, отсутствие специально организованного пространства и инфраструктуры, во-вторых, неподготовленность преподавателей к работе с людьми, имеющими особые потребности, низкий уровень методического обеспечения и сопровождения инклюзии, в-третьих, наличие стереотипов, негативных установок и страхов, предубеждений по отношению к людям с ограниченными возможностями здоровья, обусловленные зачастую отсутствием знаний о том, каким образом выстраивать взаимоотношения с ними.

Следует согласиться с позицией А.Е. Балашова и соавт. о том, что названные физические, академические, оценочные и когнитивные барьеры коррелируют между собой; для их преодоления требуется, в первую очередь, применение специальных мер, обязательно комплексного характера, а также разработки четких механизмов правового регулирования процесса образования граждан с особыми образовательными потребностями [3]. При этом, как утверждает автор, для формулирования действительно эффективного процесса обучения в высшей школе лиц с ограниченными возможностями здоровья необходима организация коллаборационного механизма, т.е. четкого взаимодействия государственного (устанавливающего правила, контролирующего их выполнение), медицинского, психологического, социологического и педагогического элементов.

Принимая во внимание названные выше барьеры развития инклюзии в высшей школе, последнему элементу важно уделить особое внимание, тем более, что с начала 2020 г. управляющим сообществом начался процесс модернизации и расширения нормативноправовой базы, касающейся развития системы образования детей и молодежи с ограниченными возможностями здоровья [11]. Аргументом в пользу сказанного являются позиции экспертов. К примеру, руководитель научно-методического центра Института проблем инклюзивного образования МГППУ Е. Самсонова считает одной из основных проблему отсутствия специальных компетенций у специалистов [14], приоритетной следи данных компетенций, с нашей точки зрения, следу- ет считать инклюзивную. Т.Ф. Краснопевцева говорит об инклюзивной компетенции специалиста, участника образовательной деятельности, как об «особой профессионально-личностной характеристике, обеспечивающей способность к осуществлению методических функций в системы высшего инклюзивного образования в соответствии с профессиональным стандартом» [10, с. 15]. На наш взгляд, инклюзивная компетенция педагога ВУЗа, будучи одной из специальных профессиональных компетенций, представляет собой знание и умение в области осуществления профессиональных функций в процессе инклюзивного образования, причем с учетом разных образовательных потребностей обучающихся, а также навык и опыт в обеспечении интеграции студента с особыми адаптивными возможностями в среду ВУЗа и создании условий для его развития и саморазвития. Мы склонны полагать, что без сформированности у педагога соответствующей компетенции, невозможно, даже при наличии иных компетентностных элементов (общий, профессиональный, частный и пр.), обеспечить эффективный и результативный образовательный процесс, и в целом, комфортное образовательное пространство.

В нашей стране есть образовательные организации дополнительного профессионального образования, которые обучают практикующих педагогов по программам, связанным с инклюзивным и интегрированным образованием детей и молодежи, однако, если оценивать масштабность социального заказа на преподавателей с соответствующим опытом, этого к сожалению недостаточно. Современные исследователи предлагают решать данную проблему или посредством интеграции некой структуры (отдела, группы специалистов медико-социального профиля или специалиста в методический отдел), в рамках которой будет разрабатываться механизм взаимодействия преподавателей и студентов с ограниченными возможностями здоровья, или с помощью специальной подготовки педагогического состава к работе в условиях инклюзии [2]. Оба варианта, по мнению Л.Ю. Беленковой следует принимать во внимание, т.к. студентам с ограниченными возможностями здоровья необходимо специализированное сопровождение в образовательном пространстве, которое благоприятствует созданию равных стартовых возможностей получения ими профессионального образования, обеспечению благоприятного социально-психологического климата в образовательной организации. Однако, следует согласиться с автором в том, что особая роль в данном случае, отводится преподавателю-наставнику (тьютору), предназначение которого состоит в актуализации и стимуляции стремлений всех студентов, вне зависимости от того, каковы их образовательные потребности, к профессиональному развитию, в создании условий для их самосовершенствования, в содействии их самоопределению, реализации образовательных, жизненных и ценностных перспектив [1, 2]. 
С нашей точки зрения, организация тьюторского сопровождения, ориентированного на совершенствование процесса обучения студентов с особыми адаптивными возможностями в ВУзе, должна быть разнонаправленная и поэтапная. Так, одним из наиболее важных считаем диагностическо-оценочное направление, первый этап тьюторской поддержки. Его основной задачей может быть определение траектории, стратегии наставника при проектировании и реализации индивидуальной образовательной программы студента с ограниченными возможностями здоровья. В данном случае, речь идет о том, что тьютор сможет определить особенности нарушений в развитии и специфику личности студента, собрать необходимые сведения о его микро-социальном окружении, выявить уровень учебной мотивации, образовательные запросы и потребности. Второй этап, соответственно, будет уже проектным; на основе данных, полученных наставником на констатирующем этапе, он сможет оптимально и в перспективе результативно разработать комплекс средств и процедур сопровождения конкретного студента или группы студентов, с учетом его (их) потребностей и возможностей. Касаемо психологических особенностей, равно как и условий, задач образования, например, наличия ярко выраженных раз- личий в сложности, темпе, объеме усвоения материала, целей профессионального развития, использования специальных технологий в процессе обучения и пр. все это обуславливает высокую ценность и значимость консультативного направления в деятельности педагога-тьютора, которое должно иметь пролонгированный эффект. Консультативное, равно как и информационнопросветительское, коррекционно-развивающее, и иные направления наставничества будут составлять третий этап процесса сопровождения, продолжительность которого будет равна продолжительности обучения студента.

Принимая во внимание выше сказанное, а также доказанную положительным зарубежным опытом интеграции (Государственный университет Вэйн (г. Детройт), Сиракузский университет (г. Сиракузы), Гарвардский университет (г. Бостон), Нью-Йоркский университет, Колумбийский университет (г. Нью-Йорк), Городской университет г. Нью-Йорка и пр. [5]) эффективность инклюзивного тьюторства, данный институт рекомендуется к актуализации, развитию и внедрению в практику национальной высшей школы, в целях систематизации и совершенствования процесса сопровождения студентов с ограниченными возможностями здоровья.

\section{ЛИТЕРАТУРА}

1. Базарнова Н.Д., Кулемалина А.И. Педагогические условия реализации наставничества в инклюзивном образовании ВУза // В сб. трудов науч.-практ. конф. «Стратегические линии развития инклюзивного высшего образования на современном этапе»; (Нижний Новгород, 26 ноября 2018 г.). - Нижний Новгород: Минский университет, 2018. - С.67-71.

2. Бакунова И.В., Морозова К.С. Роль деятельности тьютора в инклюзивном образовании // Молодежь в науке: новые аргументы: сборник докладов ІІ-й Международной молодежной научной конференции / отв. ред. А.В. Горбенко. 2015. С. 91-94.

3. Балашов А.Е., Краснова Е.А., Христофорова Л.Б. Правовые барьеры в системе вузовского инклюзивного образования // 0бразование и наука. 2020. C. 59-83.

4. Беленкова Л.Ю. Профессионально-личностная готовность преподавателей к тьюторскому сопровождению студентов с инвалидностью и ограниченными возможностями здоровья в условиях инклюзивного ВУЗа // Проблемы современного педагогического образования. 2018. №59-3. С. 76-80

5. Жаворонков Р.Н. Технология высшего инклюзивного образования инвалидов, применяемая в Соединенных Штатах Америки // Психологическая наука и образование рsyedu.ru. 2010. Т. 2. № 5. С. 13-22.

6. Зорина Е.Е. Преодоление барьеров при реализации инклюзивного образования в вузе // Образование и наука. 2018 . № 20 (5). С. 165 -184

7. Кантор В.З., Проект Ю.Л. Инклюзивное высшее образование: социально-психологическое благополучие студентов // 0бразование и наука. 2019.21 (2). C. $51-73$

8. Козырева 0.А. Актуальное нормативно-правовое обеспечение инклюзивного образования // Муниципальное образование: инновации и эксперимент. 2016. № 4. C. 58-64.

9. Кокорина Е.А. Вновь об особенностях обучения иностранному языку студентов с ограниченными возможностями здоровья на примере заикания // Высшее образование сегодня. 2019. №10. С. 71-75.

10. Краснопевцева Т.Ф. Методико-инклюзивная компетентность педагога профессионального образования как цель повышения квалификации // Вестник Мининского университета. 2018. №2 (23). 24 с.

11. «Нам катастрофически не хватает специалистов»: эксперты - о проблемах и перспективах инклюзивного образования в России. - 04.02.2020 // Агентство социальной информации. - ULR: https://www.asi.org.ru/news/2020/02/04/inklyuziya-problemy/ (дата обращения 12.10.2020)

12. Специальная психология в 2 т. Том 2: учебник для бакалавриата и магистратуры / В. И. Лубовский [и др.]; ответственный редактор В.И. Лубовский. - 7-е изд., перераб. и доп. - М.: Издательство Юрайт, 2020. - 274 с.

13. Федорова М.А., Нелепко К.С., Фандеева Д.А. Инклюзивное образование как социально-педагогический фактор модернизации высшего образования // Сб. материалов IV Всероссийской науч.-практ. конф. (с международным участием) «Профессионально-личностное развитие преподавателя и студента: 
тенденции, проблемы, перспективы» (Тамбов, 21-27 ноября 2016 г.). - Тамбов: ТГУ им. ГР. Державина, 2016. - С. 39-45

14. Эксперты: для инклюзивного образования в РФ есть законы, но не хватает практики. - 08.08.2018 // TACC. - ULR: https://tass.ru/obschestvo/5440488 (дата обращения 10.10.2020)

15. Angharad C., Beckett E. Challenging disabling attitudes, building an inclusive society': considering the role of education in encouraging nondisabled children to develop positive attitudes towards disabled people // British Journal of Sociology of Education. 2009. Vol. 30. P. 317-329.

16. Pearce M., Gray J., Campbell-Evans G. Challenges of the secondary school context for inclusive teaching / / Issues in Educational Research. 2010. Vol. 20 (3). P. 294-313.

17. Sánchez P., Rodríguez R., Martínez R. Barriers to Student Learning and Participation in an Inclusive School as Perceived by Future Education Professionals // Journal of new approaches in educational research. 2019. Vol. 8, № 1. P. 18-24

(c) Анисимова Нина Анатольевна (nina72a@gmail.com).

Журнал «Современная наука: актуальные проблемы теории и практики»

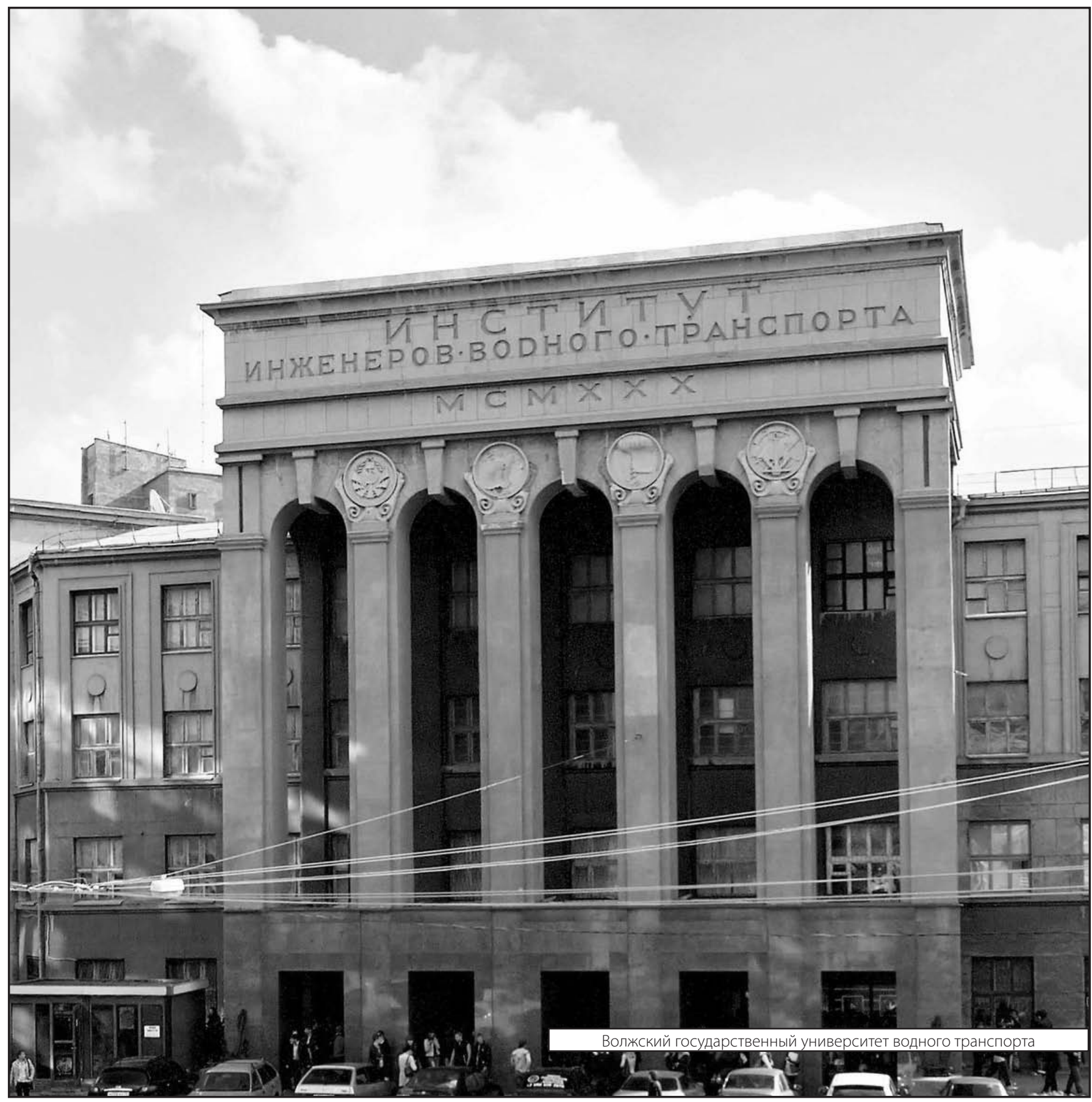

